\title{
Evaluation of the Performance of Equity Funds in Turkey
}

\author{
Serkan ÜNAL iD a Mehmet AYDINLI iD b \\ a Ufuk University, Department of Management, Ankara, Turkey. serkan.unal@ufuk.edu.tr \\ b Başkent University, Department of Banking and Finance, Ankara, Turkey. mehmet.aydinli@vakifkatilim.com.tr
}

\begin{tabular}{|c|c|}
\hline ARTICLE INFO & ABSTRACT \\
\hline $\begin{array}{l}\text { Keywords: } \\
\text { Equity Funds } \\
\text { Performance Analysis } \\
\text { Investment Style } \\
\text { FF3F }\end{array}$ & $\begin{array}{l}\text { Purpose - The young population, the ongoing inflation problem, dynamic market structure, and the } \\
\text { ongoing geopolitical risks place Turkey in a unique position in comparison with other emerging markets. } \\
\text { Recently, with the decrease in interest rates, the demand for stocks has surged and the number of stock } \\
\text { investors has increased by } 30 \% \text { in a short period of time. This situation has boosted the need for equity } \\
\text { funds, and it has become important to measure the performance of these funds effectively. The purpose } \\
\text { of this study is to measure the performance of stock funds and to determine the statistical significance } \\
\text { levels of the fund performances announced to the public on the TEFAS platform. }\end{array}$ \\
\hline $\begin{array}{l}\text { Revised } 17 \text { April } 2021 \\
\text { Accepted } 5 \text { June } 2021\end{array}$ & $\begin{array}{l}\text { Design/methodology/approach - In this study the performance of equity funds in Turkey has been tested } \\
\text { by following the FF3F approach. Firstly, reference portfolios to be used for performance comparison were } \\
\text { created. Then stock-based performances of all equity funds that operate continuously in Turkey during } \\
\text { the last five years were tested. }\end{array}$ \\
\hline $\begin{array}{l}\text { Article Classification: } \\
\text { Research Article }\end{array}$ & $\begin{array}{l}\text { Findings - According to the findings of the research, it was observed that the funds on average had } \\
\text { performances exceeding the index. However, it has been determined that the results in the TEFAS platform } \\
\text { may not be very meaningful when comparing the stock funds among themselves. } \\
\text { Discussion - Although the performance difference between the funds is high according to the TEFAS } \\
\text { platform data, it has been determined that this difference is due to the investment of some funds in small- } \\
\text { scale companies and is not sustainable. }\end{array}$ \\
\hline
\end{tabular}

\section{INTRODUCTION}

After the global financial crisis of 2008, interest rates around the world dropped significantly and the importance of stocks increased for investors who expect high returns. Equity funds managed by professionals come to the fore as an alternative investment tool because of the greater variety of stocks compared to fixed income instruments and the investments to be made in this field require more knowledge and effort. Equity funds are managed by professional managers and there is a higher cost for investors than investing directly in stocks. Therefore, investors are hesitant to invest on their own or to use the funds; and therefore, they try to answer whether the funds deserve the management fee they receive. According to Malkiel (1995: 571), the way to understand whether an investment fund manager has the talent is to compare the return of the fund he manages with the return on passive funds. Although it was observed that actively managed funds performed above the index in the 1970s, the performances of active funds have become debatable since 1980. Recent studies confirm that active funds do not outperform passive funds (Crane \& Crotty, 2018; Pástor, Stambaugh \& Taylor, 2015; Hunter, Kandel, Kandel \& Wermers, 2014). The poor performance of actively managed funds accelerates the shift to passive funds with relatively lower management fees. Considering the example of the United States, the most developed financial market in the world, the use of passive funds has increased significantly, and the ratio of money invested in passive funds following the index increased from 3\% in 1995 to 37\% at the end of 2017 (Anadu, Kruttli, McCabe, Osambela \& Shin, 2019: 1). In Turkey, although the number of funds that directly follow stock market indexes is quite limited when all funds investing in stocks are considered, it is seen that 65\% of them are closet indexers (Yalçıner, 2019: 135). 


\section{S. Ünal - M. Aydınlı 13/2 (2021) 1200-1215}

Active funds have higher research costs compared to passive funds, they can request bonuses for their performance and bear higher commission costs due to their more frequent transactions. Daniel, Grinblatt, Titman, and Wermers (1997: 1035) estimate that the difference between the management fees charged by active funds and passive funds is at the level of $1 \%$ based on managed assets. This ratio indicates a very high value considering the long-term real earnings of different investment instruments.

In actively managed funds, there are two important options for fund managers to show a performance that exceeds the index. The first of these is the right choice of stock. A long-term investment in a high performing stock will increase the performance of the fund without the need for further trading. The second is market timing. In the first alternative, only analyzing the company is mostly sufficient, while in the second alternative, macroeconomic dynamics such as market conditions, investors' risk appetite, and news flow also come into play. That's why some fund managers focus solely on choosing the right companies, while others are constantly shifting their positions by trying to time it right. Chen, Gao, Zhang, and Zhu (2018: 4) divide fund managers into two in their research. The first of these has the characteristics of sector analyst and the second one has macro analyst skills. While sector analysts focus on micro-scale by concentrating on companies; fund managers, who use a macro perspective, analyze the economy with a top-down analysis method and then select the appropriate sector and companies according to economic expectations. If we make this distinction further, there are three generally accepted investment styles in the literature. These are growth, value, and momentum factors. In particular, growth and value investment styles are accepted by major data providers such as Morningstar (Chan, Chen \& Lakonishok, 2002: 123). Mutual funds have different methods and styles. Some investment styles may come to the fore in some conjunctures. Therefore, it is difficult to measure which manager is more skilled based on the performances in a certain period.

Although the number of studies examining the performance of equity funds in developed countries is quite high, there are a limited number of studies conducted on developing countries (Wang, Paek \& Ko, 2019: 7). If we consider Turkey as a example, the number of participants in the stock market is increasing very rapidly. At the beginning of the second half of 2019, the Central Bank of Turkey (CBRT) started to reduce the interest rates. Subsequently, the COVID 19 epidemic broke out and the number of loans provided to the market through banks increased. As a result of the monetary expansion caused by these developments, it has been observed that the number of investors investing in Borsa Istanbul increased by 400k in a short period (Ekonomist, 2020). This increase in about six months has also enabled many people, who do not have sufficient knowledge and experience, to meet the stock market. These developments increase the risks of investors and expand the playing field for speculators and manipulators. As a result, the need for funds managed by professionals is increasing. This study examined the performance of funds operating in Turkey and tried to answer whether equity funds are a convenient alternative for individual investors instead of investing directly in stocks.

The past studies in Turkey, which examined the performance of the funds, were concentrated on the overall returns, not stock selections; and stated that funds did not offer the expected performances (Alptekin and Şıklar in 2009; Temizel and Bayçelebi, 2016; Yavuz and Altınırmak, 2018; Kuzubas, Saltoğlu, Sert and Yuksel, 2019). In this study, as an important contribution to the literature, the performance of the stock selections of the funds are analyzed instead of using the overall returns of the funds. Examining the performance of the selection of stocks has various advantages. First of all, the risks and returns of various stock types differ. Stockbased analysis eliminates this effect and allows measuring the performance of the fund manager more clearly. For example, the differentiation between the performances of the XU100 index and the XTUMY index is a recent case that needs to be examined in detail. While the XU100 index includes top 100 companies with the highest number of public shares traded on Borsa Istanbul, the XTUMY index includes all other Borsa Istanbul companies that are not included in the XU100 index. When the relative performances of these two indices are examined, it is seen that there has been an important trend movement in favor of the XTUMY index, which is started in August 2019. This trend, which continued until March 2020, was interrupted by the start of the Covid-19 outbreak and experienced a drastic correction. In the following period, special loan packages led by public banks were offered to consumers and an important rally took place in the XTUMY index in a falling interest rate environment (See Figure 1). In this period, the share of foreigners in Borsa Istanbul decreased from $60 \%$ to $50 \%$ and companies dominated by institutional investors did not participate in the rally (Dünya, 2020a). These developments have brought the Price / Earnings (PE) ratio of XTUMY to 74.0, although the PE 


\section{S. Ünal - M. Aydınlı 13/2 (2021) 1200-1215}

ratio of the XU100 index remained at 10.0 as of 17 July 2020 (Bloomberg, 2020). Although fund managers who have invested in companies in the XTUMY index are seen as high performers, they will have difficult times if they decide to sell these nonliquid companies, and most probably they will experience serious losses. This situation puts the assets of funds investing in companies in the XTUMY index at risk. Secondly, defensive funds may want to hold more cash position than other funds. In this way, they may have benefit from the opportunities during times of the crisis, and in cases where their own investors' exit, they can reimburse these amounts from their cash without damaging the investment positions of the fund. Although the performance of funds with a high cash position is lower than other funds during the rally periods however their risks are lower in bear markets. For this reason, a direct examination of the performance of each stock in the fund's portfolio, instead of fund's total return, will measure how effectively the fund manager chooses the stocks.

Figure 1. The Relative Performance of XTUMY and XU100 Indices

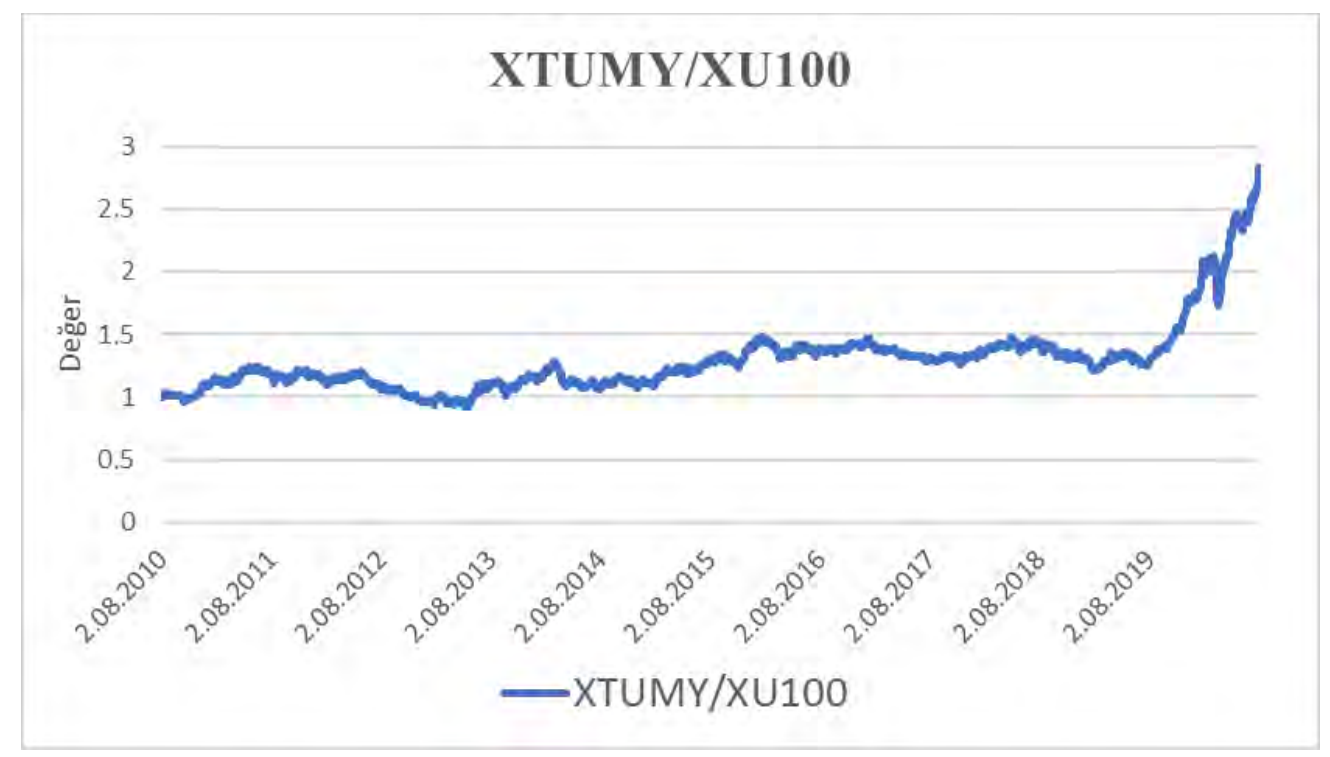

Source: Data has been retrieved from tr.investing, graphic is created by the author.

This study's other contribution to the literature is the evaluation of the validity of the reports which is supplied by the Turkish Electronic Funds Distribution Platform (TEFAS) during investment decision processes. Many investors use the TEFAS site during their fund selection process, and they tend to select the funds which have the highest returns in the reports of TEFAS. TEFAS data contains only information about the past returns of the fund but does not include details such as the amount of risk taken and the valuation of the stocks the funds have invested in. This may cause negative consequences in the future for individual investors, who tend to make decisions based on past returns. Through this study, performance analysis of funds has been conducted from a broader perspective.

Last but not least, many companies on Borsa İstanbul have low free float rates. Therefore, very high market values can be seen especially in companies with low free float ratio, and the appearance of these companies as large-scale companies renders classical valuation approaches dysfunctional. In this study, unlike other studies, normalization was made compared to free float ratios and this problem was tried to be solved.

As for the ongoing parts of the article, similar studies in the literature are presented in the second part, the research method in the third part, the research findings in the fourth part, and the conclusion and discussion in the fifth part.

\section{STUDIES EXAMINING THE RETURNS OF EQUITY FUNDS}

Lee, Jeon, Kang, and Lee (2020) examined the performance of equity funds and investigated whether these funds lead the mispricing in the market. The study includes data from 1982 to 2011 for companies listed on the United States stock exchanges. In the study, companies are divided into two groups as expensive and cheap with 15 different valuation criteria. The results show that fund managers prefer companies with higher prices and therefore they perform below than the performance of the index. Besides, when the funds are 


\section{S. Ünal - M. Aydınlı 13/2 (2021) 1200-1215}

compared among themselves, it is revealed that the performance of the funds are higher which invests in companies that have higher scores according to 15-criteria rating system.

Wang et al. (2019) examined the performance of fund managers in the Chinese stock market by using the LGWT model. According to the findings obtained, fund managers in China exhibit superior performance in terms of selection and timing. Another striking finding is that the average performance of the funds is only as much as the market return and when the total returns of all funds are considered, no performances exceeding the index are achieved.

Deb (2019) examined 263 Indian funds in his study and investigated whether the performance of the funds is sustainable. According to the findings obtained, while high performing funds generally cannot maintain their high performance, it is observed that funds with poor performance continue to remain in the lower ranks. Another finding is that the performance of large and older funds is higher than that of small and young funds. Findings from the study show that the markets of developing countries such as India are not functioning effectively yet, and the past fund performances may be an indicator for the future, albeit partially.

In their study examining the performance of funds in Indonesia, Setiawan and Kanila (2019) used data from 8 funds between 2010 and 2018. According to the findings, stock selection ability, the size of the assets, and the inflation rate positively affect the performance of equity funds. On the other hand, it was observed that the market timing ability did not have a statistically significant effect on the returns of these funds.

Broeders, Van Oord, and Rijsbergen (2019) investigated the performance of the pension fund managers who use different investment instruments and invest on the Dutch stock exchange and tried to answer whether these funds deserve the performance fee they receive. According to their findings (1) it is seen that pension funds paying performance premium to fund managers achieve the same level of return compared to other funds; (2) if pension funds invest money in hedge funds and pay performance fees, then the outcome will change and there will be higher returns compared to the market; (3) large-scale funds generate higher returns than other funds.

Kuzubas, Saltoğlu, Sert, and Yüksel (2019), whose study covers the years between 2003 and 2018, have examined the performance of pension funds operating in Turkey. According to the findings, when the performance after management fees is considered, all types of funds except equity funds perform lower than the security class they follow. In the same study, it was also investigated whether the performance is sustainable or not, and it was found that some fund managers could maintain high performance partially.

Sevinç and Yakar (2019) examined the risk levels of the funds in their study, in which they included twentyeight equity funds operating between 2014 and 2018. They found that a significant portion of the funds have lower than market performance and the funds with low performance were also riskier according to reference criteria used in the study.

Yavuz and Altınirmak (2018) used data between 2012 and 2016 and analyzed the performance of umbrella funds in Turkey according to the Morningstar rating system. They found that majority of the funds have low Morningstar scores. In addition, there is no significant relationship between Morningstar grade and the performance of the fund.

Gökçen and Yalçın (2015) have analyzed the performance of pension funds operating in Turkey between 2003 and 2011. By using weekly data, they found that these funds could not outperform the index and the funds that performed successfully in certain years could not maintain superior performance in the following years.

In their study, Korteweg and Sorensen (2017) tried to determine whether luck or talent is a determinant in the performance of funds. In the study using data from 1924 different funds in the United States between 1969 and 2001, the performance of high-performing and low-performing funds in the following years was examined. According to the results obtained, it has been observed that the performance difference between the highest and lowest quartile funds continues to be between $7 \%$ and $8 \%$ annually in the following periods.

Guzella and Campani (2017) used data from 867 funds between 2004 and 2014 to investigate whether the funds' selection criteria and past performances are determinants of future performances. In the research, the data that the fund's return can be explained by the market return is used as the selection criteria. Accordingly, it is assumed that the funds with low $\mathrm{R}^{2}$ values apply a higher rate of selection criteria and differ from the 


\section{S. Ünal - M. Aydınlı 13/2 (2021) 1200-1215}

market performance. According to the findings, funds that apply a higher rate of selection criteria and funds that have performed well in the past show higher performance in the following periods.

Şahin (2017) analyzed the performance of 7 BIST30 index funds between 2005 and 2015 and found that all of the funds had a statistically significant negative alpha in the Jensen model estimate and that all funds underperformed the index they followed.

Temizel and Bayçelebi (2016) examined the performance of 213 mutual funds in Turkey between 2013 and 2015 by data envelopment analysis method. According to the results obtained from the study, there was a decrease in the overall efficiency of the mutual fund industry in Turkey. The findings show that the funds of debt securities are preferred in Turkey although the equity funds are most popular in other developing countries.

In their study, Robinson and Şensoy (2013) used data from 837 funds operating in the United States between 1984 and 2010. They investigated whether there is a relationship between fund managers' performance fees and fund performance. It has been observed that there is an increase in performance fees, especially during periods of increased interest in funds. According to the findings, the performance of fund managers with higher wages is higher than other fund managers. In the same study, the relationship between fund manager's ownership rate in the fund and their performance was also examined, and it was found that there was a strong relationship between the ownership rate of managers and the fund performance.

Korkmaz and Uygurtürk (2008) analyzed the performance of funds in Turkey between 2004 and 2006. They reported that funds have not sufficient performance in terms of risk criteria of the research and only one of the 17 funds included in the study has the ability of market timing.

Daniel et al. (1997) in their study, included 2500 stock funds operating in the United States between 1975 and 1994 and measured the performance of these funds against various indicators. In the research, while measuring the performance of the funds, stock-based performance data was used, and 125 passive portfolios based on three basic criteria were created in order to measure the performance of these stocks effectively. While creating passive portfolios, characteristic timing, characteristic selection, and average style variables are used as basic criteria. The characteristic timing indicates whether the fund is investing in the right companies at the right time, the characteristic choice is whether it chooses the best from the companies with the same characteristics, and the average style indicates whether the fund holds the positions on the companies with high performance in the long term. According to the findings of the research, the superior performance that active fund management can achieve on average compared to mechanically formed portfolios is only high enough to meet the additional management fee. Therefore, there is no concrete reason to choose actively managed funds when considering their overall performance for investors. However, it may be the case that some of the funds that are actively managed outperform other active funds.

Studies in the literature show that funds are not able to deliver the expected returns in many countries. In this study, as a contribution to the literature, the stock-based performances of the funds were examined in a developing market.

\section{METHOD}

\subsection{Data Set}

Firstly, the equity funds operating in Turkey have been identified by using data from TEFAS. Then, the index funds, the funds that invest only in a certain sector or group of companies, and the funds invest in abroad are sorted out among these funds. It is considered that it would not be correct to evaluate the performance of the funds which invests certain companies; as the performance of companies with different characteristics periodically differed and this selection was made beforehand, except for the fund manager's decision-making authority. In this way, it is aimed to eliminate the bias effect that may affect the performance of fund management. Accordingly, 21 out of a total of 44 funds were excluded from the scope of the study, of which, 6 following the index, 8 investing only in foreign markets, 2 investing only in the affiliates of a certain group, 2 investing only in companies that pay dividends, and 3 investing only in companies in a certain sector. Data of 1 fund could not be included in the scope since the fund did not report the details of stock holdings. 


\section{S. Ünal - M. Aydınlı 13/2 (2021) 1200-1215}

Within the scope of the study, 22 equity funds operating for the entire five-year period between September 2015 and June 2020 and meeting the above criteria were included. Portfolio distribution reports of these stock funds, published on the Public Disclosure Platform website, were downloaded quarterly to cover the last five years, and share-based data were transferred to the excel environment. 4554 stocks reported in the 5-year * 4 period (440) public closures of 22 stock funds in total were finally included in the study. The number of stocks included within the scope of the research is given in Table 1.

Table 1. Number of Stocks Included in the Research Scope

\begin{tabular}{cccccc}
\hline Sep-15 & 148 & Jun-17 & 209 & Mar-19 & 269 \\
Dec-15 & 164 & Sep-17 & 217 & Jun-19 & 254 \\
Mar-16 & 165 & Dec-17 & 262 & Sep-19 & 283 \\
Jun-16 & 163 & Mar-18 & 240 & Dec-19 & 270 \\
Sep-16 & 164 & Jun-18 & 295 & Mar-20 & 277 \\
Dec-16 & 171 & Sep-18 & 271 & Jun-20 & 290 \\
Mar-17 & 182 & Dec-18 & 260 & Total & 4.554 \\
\hline
\end{tabular}

For the tests to be applied within the scope of the research, financial statements, and stock price performance data of companies operating in Borsa Istanbul were required. Stock price performance data were retrieved from Yahoo Finance website, financial statement data from İsyatırım website, treasury bills interest rates from tr.investing website, and data regarding the performance of funds from TEFAS website.

\subsection{Research Model}

\subsubsection{Model Selection}

As stated in the introduction, the performance of equity funds based on stock selection is analyzed within the scope of this research. The three asset pricing models frequently used in the literature are CAPM, developed by Sharpe (1964), FF3F developed by Fama and French (1993), and FF5F also developed by Fama and French (2015). Although CAPM, which is the price determination approach compared to the expected return of the market based on risk, has been the most frequently used approach as the main asset pricing model for about 30 years, it has been subjected to various criticisms in the 1990s. Especially the studies indicating that there is a relationship between company size, market value/book value ratio, growth in sales, and return have revealed the shortcomings of CAPM (Belimam, Tan \& Lakhnati, 2018: 249). The FF3F model, which emerged at this point and explains the returns of stocks with risk-free earnings ratio, market return, the performance difference between small and large companies, and book value/market value variables, gained popularity in the following years. In 2015, the FF5F model was created by adding profitability and investment criteria to the assumptions of the classic FF3F model.

When the studies conducted in Turkey are considered, the validity of the FF3F model in Borsa İstanbul has been tested frequently. In general, the findings confirm the validity of this model in Borsa İstanbul (Atakan \& Gökbulut, 2010; Coşkun \& Çınar, 2014; Kara, 2016; Kaya \& Güngör, 2017). Only, the study of Genç and Çömlekçi (2018: 271) which covers companies included in the Borsa Istanbul corporate governance index between 2010 and 2017, found that small-scale companies performed lower than large-scale companies, unlike FF3F main assumptions. Acaravcı and Karaome (2017), Aras, Çam, Zavalsız, and Keskin (2018), among the studies on the relatively new FF5F model, confirmed the validity of the model however Zeren, Y1lmaz, and Belke (2019) could not find positive results regarding the validity of the FF5F model.

Among the studies examining three different models and comparing their performance compared to each other, Belimam, Tan, and Lakhnati (2018: 251) reported that the FF3F model is superior to both CAPM and FF5F models in their research examining the Chinese market. Hanauer and Lauterbach (2019: 281) who tested the validity of CAPM, FF3F, and FF5F models during the 21 years in 28 different emerging countries including Turkey, found that FF3F model has superior results in comparison with other models. 


\section{S. Ünal - M. Aydınlı 13/2 (2021) 1200-1215}

FF3F model has been tested and validated many times in Turkey and recent research shows its superiority over other models in many different developing countries, therefore FF3F model is preferred in this study.

\subsubsection{Preparation of the Data Set Required for Model Testing}

The equation for the Fama and French (1993) FF3F model used in the study is defined below.

$R_{i}(t)-R f(t)=\alpha_{i}+\beta_{i}(R m(t)-R f(t))+S_{i} S M B(t)+h_{i} H M L(t)+e_{i}(t)$

$\mathrm{R}_{i}(\mathrm{t})$ shows the quarterly price performance of share $i$ at period $t ; \operatorname{Rf}(t)$ shows the 3-month bond interest yield; $\alpha_{\mathrm{i}}$ is the fixed coefficient showing the abnormal performance of the fund; $\beta_{\mathrm{i}}, \mathrm{Si}$ and $\mathrm{h}_{\mathrm{i}}$ are the beta values of different factors; $\mathrm{Rm}(\mathrm{t})$ shows the return of companies in Borsa Istanbul in the period of $t$; SMB ( $t$ ) shows the return of companies with small market value (MV) compared to companies with large market value (MV) in period $t$; HML ( $t$ ) is the return of companies with high book value / market value (BV / MV) ratio compared to companies with low BV / MV ratio in $\mathrm{t}$ period; $\mathrm{e}_{\mathrm{i}}(\mathrm{t})$ shows the error term in the period $\mathrm{t}$.

Due to the low free float ratio in certain stocks in Borsa Istanbul, problems are encountered in applying the FF3F model compared to developed countries. Previous studies examining the relationship between free float ratios and company performance in Borsa Istanbul show that companies with low free float ratios are exposed to stricter price movements (Barak, 2007: 70); the free float ratio in Turkey is not at a desirable level and there is an inverse relation between free float ratio and Tobin's q ratio which indicates the valuation of the companies (Kesbiç and Taşdemir, 2019: 700); and the free float ratio and profitability have a negative relationship (Meydan and Yllmaz, 2020: 83). Besides, it is observed that companies with very low free float ratio can have a very high market value compared to fundamental valuation criteria. For example, QNB Finansbank, which is one of the medium-sized banks in Turkey, reached a market value of $\$ 40$ billion in January 2020 with a free float ratio of only $0.1 \%$ and became representing $20 \%$ of Borsa Istanbul alone (Bloomberght, 2020). Similarly, unexpected price movements were observed in other examples such as the Kalkınma ve Yatırım Bankası and Kent Gida shares, with free float ratios of $0.9 \%$ and $0.5 \%$, respectively (Dünya, 2020b). To prevent some lowfree float stocks from appearing among companies with high market value due to abnormal price movements, the publicly traded MV criterion was used instead of MV in the formation of SMB sub-series.

To calculate the SMB and HML series, companies are grouped according to publicly traded MV and BV / MV ratios. In the classification according to the publicly traded MV, the 50\% portion with the smallest market value is named as "S", and the shares in the $50 \%$ portion with the large publicly traded market value are named as "B". In the BV / MV ranking, the companies in the top 30\% are named " $\mathrm{H}$ ", the companies falling between $30 \%$ and $70 \%$ are "M" and the companies between $70 \%$ and $100 \%$ in the ranking are called "L". Later, $\mathrm{SH}, \mathrm{BH}$, SM, BM, SL and BL groups were created to cover the intersection clusters specified in Table 2.

Table 2. Formation of the SH, BH, SM, BM, SL and BL Groups

\begin{tabular}{|c|c|c|c|c|}
\hline \multirow{4}{*}{$\begin{array}{c}\text { Publicly Traded } \\
\text { Market Value } \\
\text { (MV) } \\
\text { Classification }\end{array}$} & & \multicolumn{3}{|c|}{ Book Value/Market Value (BV/MV) Classification } \\
\hline & & $\mathbf{H}$ & $\mathbf{M}$ & $\mathbf{L}$ \\
\hline & B & $\mathrm{BH}$ & $\mathrm{BM}$ & BL \\
\hline & $\mathrm{s}$ & $\mathrm{SH}$ & $\mathrm{SM}$ & SL \\
\hline
\end{tabular}

After the relevant subgroups are created, equation (2) and equation (3) are used in the calculation of SMB and HML series as follows.

$$
\begin{aligned}
& \mathrm{SMB}=(\mathrm{SH}+\mathrm{SM}+\mathrm{SL}) / 3-(\mathrm{BH}+\mathrm{BM}+\mathrm{BL}) / 3 \\
& \mathrm{HML}=(\mathrm{SH}+\mathrm{BH}) / 2-(\mathrm{SL}+\mathrm{BL}) / 2
\end{aligned}
$$




\section{S. Ünal - M. Aydınlı 13/2 (2021) 1200-1215}

After preparing the FF3F model data for the independent variables, to test the validity of the performance data specified in TEFAS, the funds were divided into 4 different quartiles by ranking according to their total returns of the last five years. Afterward, a data set for regression analysis was prepared by creating a total of 5 different models, including the model for all funds and the model for 4 different quartiles according to their rankings in TEFAS 5-year return data.

The stock holdings of the funds were compiled from the relevant public disclosure platform notifications and the information on which stock and how much the fund invested in each stock was included in the data set. According to the communique on the principles regarding investment funds published by the $\mathrm{CMB}$, fourth chapter, article 17 , more than $10 \%$ of the total value of the fund cannot be invested in the capital market instruments of an issuer (CMB, 2013: 11). This criterion has greatly increased the diversity in the number of stocks invested by funds; on the other hand, there are some small positions in the portfolios of the funds that will not have a significant effect on the total return. In order that the returns of these stocks do not adversely affect the results, a minimum of $2 \%$ ratio requirement has been used for the stocks to be included in the study. Due to this limitation, $17 \%$ of the amount invested by the funds in total has been excluded from the model. In this way, a more homogeneous distribution of weights between $2 \%$ and $10 \%$ was obtained while a high representation of $83 \%$ was saved in the total data set. Finally, the stock positions of the funds are included in 4 different models based on their return rankings in TEFAS.

Average returns of 4 quartiles and all funds are shown in Table 3.

Table 3. Classification of the Funds According to the Last Five Years Returns

\begin{tabular}{|c|c|c|c|c|}
\hline $\begin{array}{l}5 \text { Year Return } \\
\text { Ranking }\end{array}$ & \# of Funds & 1 Year (\%) & 3 Year (\%) & 5 Year (\%) \\
\hline (1) (Highest) & 5 & 89.9 & 136.3 & 243.0 \\
\hline (2) & 6 & 41.2 & 71.7 & 130.3 \\
\hline (3) & 6 & 23.8 & 42.0 & 82.9 \\
\hline (4) (Lowest) & 6 & 23.4 & 26.7 & 63.4 \\
\hline Overall & 23 & 42.6 & 66.3 & 125.0 \\
\hline
\end{tabular}

Source: Prepared by the author using TEFAS data.

\subsubsection{Limitations of the Research}

Since the continuity of funds in the relevant period criterion is taken into account in this research, only the data of the last five years are included in the scope to make the number of funds as much as possible. So that the small positions do not affect the results in the model, stocks with a weight less than $2 \%$ of the fund assets were excluded, which reduced the representation power to $83 \%$. The study covers only general equity funds, therefore the funds investing in a certain index or investing according to certain criteria as per the definition in the fund regulation are not covered. The study includes only funds in Turkey.

\section{FINDINGS}

Descriptive statistics are presented in Table 4 by adhering to the classified quartiles in Table 3 . The no of quartile, the relevant Rit_Rft value belongs to, is indicated in parentheses. When the descriptive statistics are examined, it is noteworthy that the stocks in the first quartile have higher standard deviations compared to the other quartiles. The difference between the maximum and minimum values is higher in quartiles 1 and 2 compared to other quartiles. Another striking factor is that the number of observations in the 3rd and 4th quartiles is higher. This situation indicates that funds with poor performance, in the long run, attach more importance to diversity. 
Table 4. Descriptive Statistics

\begin{tabular}{|c|c|c|c|c|c|c|c|c|}
\hline & $\begin{array}{l}\text { Rit_Rft } \\
\text { (Genel) }\end{array}$ & $\begin{array}{c}\text { Rit_Rft } \\
\text { (Highest } \\
\text { Performing) } \\
\text { (1) }\end{array}$ & $\begin{array}{c}\text { Rit_Rft } \\
\text { (2) }\end{array}$ & $\begin{array}{c}\text { Rit_Rft } \\
\text { (3) }\end{array}$ & $\begin{array}{c}\text { Rit_Rft } \\
\text { (Lowest } \\
\text { Performing) } \\
\text { (4) } \\
\end{array}$ & MKT_Rf & HML & SMB \\
\hline Average & 0,016 & 0,029 & 0,029 & 0,017 & 0,001 & 0,083 & $-0,044$ & 0,064 \\
\hline Median & 0,00 & 0,01 & 0,01 & 0,01 & $-0,01$ & 0,05 & $-0,07$ & 0,02 \\
\hline Maximum & 1,10 & 1,10 & 0,92 & 0,74 & 0,89 & 0,68 & 0,35 & 0,33 \\
\hline Minimum & $-0,61$ & $-0,61$ & $-0,52$ & $-0,52$ & $-0,61$ & $-0,17$ & $-0,17$ & $-0,07$ \\
\hline Standard Dev. & 0,20 & 0,21 & 0,21 & 0,19 & 0,20 & 0,20 & 0,11 & 0,10 \\
\hline Skewness & 0,65 & 0,90 & 0,79 & 0,43 & 0,52 & 1,63 & 2,24 & 1,06 \\
\hline Kurtosis & 4,72 & 5,25 & 4,89 & 4,02 & 4,41 & 5,54 & 8,44 & 3,88 \\
\hline Probability & 0,00 & 0,00 & 0,00 & 0,00 & 0,00 & 0,00 & 0,00 & 0,00 \\
\hline Observations & 4466 & 964 & 734 & 1256 & 1512 & 4466 & 4466 & 4466 \\
\hline
\end{tabular}

Values in parentheses show the fund quartiles ranked according to their performance. The funds offering the highest return in the last five years are in the 1st quartile, while the funds offering the lowest return are in the 4th quartile. Rit_Rft shows the return of the stock $i$ compared to the risk-free earnings at time $t$ in specified quartiles; MKT_Rf shows the performance of market return compared to risk-free earnings, HML shows the performance of companies with high $B V / M V$ compared to companies with low BV / MV, and SMB shows the performance of companies with low publicly traded market value compared to companies with large publicly traded market value.

In Table 5, correlation values of dependent and independent variables are given separately for models belonging to different quartiles. In general, the correlation coefficients are similar between different quartiles. When the correlation values between independent variables are examined, relatively low values are observed, but the correlation coefficient between HML and SMB is higher compared to other coefficients.

Tablo 5. Correlation Matrix

\begin{tabular}{|c|c|c|c|c|c|c|c|c|c|c|c|}
\hline & & & & \multicolumn{2}{|c|}{ Rit_Rft } & \multicolumn{2}{|r|}{ MKT_Rf } & \multicolumn{2}{|r|}{ HML } & \multicolumn{2}{|c|}{ SMB } \\
\hline \multirow{3}{*}{\multicolumn{2}{|c|}{ Overall }} & \multicolumn{2}{|l|}{ Rit_Rft } & \multicolumn{2}{|c|}{1.00} & \multicolumn{2}{|r|}{0.58} & \multicolumn{2}{|r|}{0.00} & \multicolumn{2}{|c|}{0.00} \\
\hline & & \multicolumn{2}{|l|}{ MKT_Rf } & \multicolumn{2}{|c|}{0.58} & \multicolumn{2}{|r|}{1.00} & \multicolumn{2}{|r|}{-0.07} & \multicolumn{2}{|c|}{0.35} \\
\hline & & \multicolumn{2}{|l|}{ HML } & \multicolumn{2}{|c|}{0.00} & \multicolumn{2}{|r|}{-0.07} & \multicolumn{2}{|r|}{1.00} & \multicolumn{2}{|c|}{0.46} \\
\hline & & \multicolumn{2}{|l|}{ SMB } & \multicolumn{2}{|c|}{0.00} & \multicolumn{2}{|r|}{0.35} & \multicolumn{2}{|r|}{0.46} & \multicolumn{2}{|c|}{1.00} \\
\hline & & Rit_Rft & MKT_Rf & HML & SMB & & & Rit_Rft & MKT_Rf & HML & SMB \\
\hline \multirow{4}{*}{$\begin{array}{c}(1) \\
\text { Funds } \\
\text { with } \\
\text { Highest } \\
\text { Return }\end{array}$} & Rit_Rft & 1.00 & 0.59 & -0.01 & 0.06 & \multirow{4}{*}{$\begin{array}{c}\text { (3) } \\
\text { Funds } \\
\text { with } \\
\text { Low } \\
\text { Return }\end{array}$} & Rit_Rft & 1.00 & 0.55 & 0.05 & -0.02 \\
\hline & MKT_Rf & 0.59 & 1.00 & -0.05 & 0.35 & & MKT_Rf & 0.55 & 1.00 & -0.07 & 0.34 \\
\hline & HML & -0.01 & -0.05 & 1.00 & 0.47 & & HML & 0.05 & -0.07 & 1.00 & 0.43 \\
\hline & SMB & 0.06 & 0.35 & 0.47 & 1.00 & & SMB & -0.02 & 0.34 & 0.43 & 1.00 \\
\hline \multirow{4}{*}{$\begin{array}{c}(2) \\
\text { Funds } \\
\text { with } \\
\text { High } \\
\text { Return }\end{array}$} & Rit_Rft & 1.00 & 0.57 & -0.01 & -0.01 & \multirow{4}{*}{$\begin{array}{c}(4) \\
\text { Funds } \\
\text { with } \\
\text { Lowest } \\
\text { Return }\end{array}$} & Rit_Rft & 1.00 & 0.61 & -0.01 & 0.00 \\
\hline & MKT_Rf & 0.57 & 1.00 & -0.04 & 0.34 & & MKT_Rf & 0.61 & 1.00 & -0.08 & 0.35 \\
\hline & HML & -0.01 & -0.04 & 1.00 & 0.45 & & HML & -0.01 & -0.08 & 1.00 & 0.48 \\
\hline & SMB & -0.01 & 0.34 & 0.45 & 1.00 & & SMB & 0.00 & 0.35 & 0.48 & 1.00 \\
\hline
\end{tabular}

The overall category includes all 22 funds, while the other four quartiles include the respective funds according to the previously stated performance ranking.

To decide on the model to be used, several pre-tests must be done first. First of all, it was determined whether the data are stationary or not by performing the stationarity test. The series are determined to be stationary by applying the extended Dickey-Fuller (ADF) test. 
S. Ünal - M. Aydınlı 13/2 (2021) 1200-1215

Tablo 6. Extended Dickey-Fuller (ADF) Test Results

\begin{tabular}{lcccccccc}
\hline & $\begin{array}{c}\text { Rit_Rft } \\
\text { (Overall) }\end{array}$ & $\begin{array}{c}\text { Rit_Rft } \\
(\mathbf{1})\end{array}$ & $\begin{array}{c}\text { Rit_Rft } \\
\mathbf{( 2 )}\end{array}$ & $\begin{array}{c}\text { Rit_Rft } \\
\mathbf{( 3 )}\end{array}$ & $\begin{array}{c}\text { Rit_Rft } \\
\mathbf{( 4 )}\end{array}$ & MKT_Rf & HML & \multirow{2}{*}{ SMB } \\
\hline $\mathbf{t}$ stat & -14.55 & -10.03 & -7.42 & -11.09 & -9.75 & -10.51 & -11.15 & -9.57 \\
\hline probability & 0.00 & 0.00 & 0.00 & 0.00 & 0.00 & 0.00 & 0.00 & 0.00 \\
\hline
\end{tabular}

For the linear regression model to be applied, the validity of three different assumptions must be confirmed. These are (1) the assumption that there is no multicollinearity between the independent variables, (2) the assumption that variance of error terms are similar, and finally (3) the assumption that there is no autocorrelation regarding the relationship between the values of the error term ( Tar1, 2018: 157). The variance inflation factor (VIF) test was used to determine the multicollinearity, the White test to determine the heteroskedasticity, and the Durbin-Watson d statistics to determine the autocorrelation.

VIF values of different models within the scope of the research are given in Table 7. VIF values less than 5 indicate that there is no multicollinearity (Tarı, 2018: 162).

Tablo 7. VIF Test Results

\begin{tabular}{|c|c|c|c|c|}
\hline & Model & MKT_RF & HML & SMB \\
\hline \multirow{5}{*}{ Coefficient Variance } & Overall & 0,00 & 0,00 & 0,00 \\
\hline & (1) (Highest) & 0,00 & 0,00 & 0,00 \\
\hline & $(2)$ & 0,00 & 0,00 & 0,01 \\
\hline & (3) & 0,00 & 0,00 & 0,00 \\
\hline & (4) (Lowest) & 0,00 & 0,00 & 0,00 \\
\hline \multirow{5}{*}{ Uncentered VIF } & Overall & 1,43 & 1,57 & 2,18 \\
\hline & (1) (Highest) & 1,40 & 1,58 & 2,22 \\
\hline & $(2)$ & 1,36 & 1,56 & 2,04 \\
\hline & $(3)$ & 1,43 & 1,52 & 2,01 \\
\hline & (4) (Lowest) & 1,48 & 1,63 & 2,40 \\
\hline \multirow{5}{*}{ Centered VIF } & Overall & 1,22 & 1,36 & 1,54 \\
\hline & (1) (Highest) & 1,22 & 1,37 & 1,55 \\
\hline & $(2)$ & 1,19 & 1,33 & 1,50 \\
\hline & (3) & 1,20 & 1,31 & 1,47 \\
\hline & (4) (Lowest) & 1,26 & 1,43 & 1,62 \\
\hline
\end{tabular}

The White test was applied to determine the presence of heteroskedasticity. The $\mathrm{H}_{0}$ hypothesis, which states that there is varying variance, was rejected at the $1 \%$ significance level for all models. Regression analyzes were used in models that were found to have no multicollinearity and heteroskedasticity. In the regression analysis, Durbin-Watson statistics were also calculated, and it was determined that there was no autocorrelation in the series because these values were close to 2 . The results of the analysis made with the least-squares method are given in Table 8. According to the findings obtained from the regression analysis, all independent variables are statistically significant at $1 \%$ level in all models. The constant-coefficient showing the alpha of the funds is significant at a $1 \%$ level in all models except model 4 .

When the results of the MKT_RF factor, which expresses the market return compared to risk-free income, are analyzed, it is observed that the sensitivity coefficient for the market return of the funds is around 0.7. This value lower than 1 show that stock funds choose companies with relatively low beta. When the results according to performance ranking are analyzed, the coefficient in the model number 1, representing the funds with the highest performance, is higher than the other models, while the lowest coefficients were obtained in the models 3 and 4 . This coefficient also indicates the sensitivity of the funds to market risk, and it has been observed that the funds generally achieve similar results. 
When the results of the HML factor are examined, it is seen that all fund quartiles prefer discounted companies in terms of BV / MV and have a positive coefficient. Especially, it is observed that the HML coefficients of the funds in the 3rd and 4th quartiles are higher, in other words, the funds in these quartiles are more careful in choosing shares in terms of the value premium, unlike their low performances.

When the SMB factor is examined, it is determined that all fund quartiles have a negative coefficient. This may be due to the funds managing large scale assets and may not have a chance to invest in companies with low market value. On the other hand, it is observed that the coefficient of Model 1, which includes the highest performing funds, is higher than other models, meaning that the funds in this quartile invest more in smallcap companies compared to other quartiles.

Table 8. Results of the Regression Analysis

\begin{tabular}{|c|c|c|c|c|c|c|}
\hline & & Overall & $\begin{array}{c}\text { (1) } \\
\text { Funds } \\
\text { with } \\
\text { Highest } \\
\text { Return } \\
\end{array}$ & $\begin{array}{l}\quad \text { (2) } \\
\text { Funds } \\
\text { with High } \\
\text { Return }\end{array}$ & $\begin{array}{c}\text { (3) } \\
\text { Funds with } \\
\text { Low } \\
\text { Return }\end{array}$ & $\begin{array}{l}\text { (4) } \\
\text { Funds with } \\
\text { Lowest Return }\end{array}$ \\
\hline \multirow{3}{*}{ MKT_RF } & Coefficient & 0.70 & 0.73 & 0.72 & 0.65 & 0.71 \\
\hline & Std. Error & $(0.01)$ & $(0.03)$ & $(0.03)$ & $(0.02)$ & $(0.02)$ \\
\hline & Prob. & 0.00 & 0.00 & 0.00 & 0.00 & 0.00 \\
\hline \multirow{3}{*}{ HML } & Coefficient & 0.36 & 0.28 & 0.29 & 0.43 & 0.38 \\
\hline & Std. Error & $(0.02)$ & $(0.06)$ & $(0.06)$ & $(0.04)$ & $(0.04)$ \\
\hline & Prob. & 0.00 & 0.00 & 0.00 & 0.00 & 0.00 \\
\hline \multirow{3}{*}{ SMB } & Coefficient & -0.68 & -0.55 & -0.66 & -0.69 & -0.74 \\
\hline & Std. Error & $(0.03)$ & $(0.07)$ & $(0.07)$ & $(0.05)$ & $(0.05)$ \\
\hline & Prob. & 0.00 & 0.00 & 0.00 & 0.00 & 0.00 \\
\hline \multirow{3}{*}{$\mathrm{C}$} & Coefficient & 0.02 & 0.02 & 0.03 & 0.02 & 0.01 \\
\hline & Std. Error & $(0.003)$ & $(0.008)$ & $(0.008)$ & $(0.006)$ & $(0.005)$ \\
\hline & Prob. & 0.00 & 0.01 & 0.00 & 0.00 & 0.23 \\
\hline \multicolumn{2}{|c|}{ Adjusted $R^{2}$} & 0.41 & 0.39 & 0.39 & 0.40 & 0.46 \\
\hline \multicolumn{2}{|c|}{ Durbin-Watson Stat } & 1.86 & 1.91 & 1.91 & 1.80 & 1.92 \\
\hline \multicolumn{2}{|c|}{ White Test } & 0.00 & 0.00 & 0.00 & 0.00 & 0.00 \\
\hline
\end{tabular}

As stated in the introduction, there is a significant divergence between the performance of the XTUMY and XU100 indices. Besides, according to the results obtained from the regression analysis, the SMB factor, which indicates the public market values of companies, should be examined in more detail. Therefore, the selection criteria and performances of the quartiles formed according to the funds return order is examined in more detail in Table 9, Table 10, and Table 11.

In Table 9, using the FF3F model classification, the stock preferences of the funds are shown. It is observed that funds with a high return rate prefer companies with a low market value significantly more than other funds.

Table 9. The Stock Selections of Fund Quartiles According to FF3F Model Classification (\%)

\begin{tabular}{ccccccccc}
\hline $\begin{array}{c}\text { Funds Classified } \\
\text { According to } \\
\text { Their Returns }\end{array}$ & BH & BM & BL & SH & SM & SL & $\begin{array}{c}\text { B } \\
\text { Total }\end{array}$ & $\begin{array}{c}\text { S } \\
\text { Total }\end{array}$ \\
\hline (1) (Highest) & 32.1 & 39.1 & 19.2 & 3.6 & 5.2 & 0.9 & 90.4 & 9.6 \\
\hline$(2)$ & 25.2 & 40.2 & 34.2 & 0.1 & 0.1 & 0.3 & 99.5 & 0.5 \\
\hline$(3)$ & 25.6 & 39.3 & 33.8 & 0.1 & 0.9 & 0.3 & 98.7 & 1.3 \\
\hline (4) (Lowest) & 28.2 & 41.6 & 28.6 & 0.4 & 1.0 & 0.1 & 98.4 & 1.6 \\
\hline
\end{tabular}




\section{S. Ünal - M. Aydınlı 13/2 (2021) 1200-1215}

According to TEFAS reports, quartile number 1 includes the funds that have achieved the highest return in the last five years, while quartile number 4 includes the funds with the lowest return.

Table 10 shows the returns obtained by the funds based on stocks classified according to the FF3F model. The funds in the first quartile performed higher only in $\mathrm{BH}$ and SL class stocks compared to other quartiles. Fund quartile 2 achieved above-average returns in companies with both high market value and low market value. Quartile number 4 generally has failure in different classes. Besides, when looking at the general averages, it is seen that the group $\mathrm{S}$ consisting of small-cap companies has a return average of $9.3 \%$, and the average return of group B, which is composed of stocks with large market cap, is only $4.8 \%$. Funds investing in small cap stocks at a higher rate, where higher risk and speculative pricing can be found, may naturally have higher performance.

Table 10. Quarterly Average Return Rates Obtained from Stocks Classified According to Fund Quartiles, and FF3F Classification (\%)

\begin{tabular}{cccccccccc}
\hline $\begin{array}{c}\text { Funds Classified } \\
\begin{array}{c}\text { According to } \\
\text { Their Returns }\end{array}\end{array}$ & BH & BM & BL & SH & SM & SL & B & S & Total \\
\hline$(1)$ (Highest) & $\mathbf{3 . 5 2}$ & 5.68 & 6.53 & 6.20 & 7.36 & $\mathbf{2 1 . 2 6}$ & 5.04 & 8.15 & 5.33 \\
\hline$(2)$ & 2.89 & $\mathbf{7 . 4 4}$ & $\mathbf{7 . 0 7}$ & 7.78 & $\mathbf{7 7 . 0 7}$ & 20.56 & 6.13 & 28.51 & 6.24 \\
\hline$(3)$ & 2.70 & 5.93 & 5.24 & $\mathbf{8 . 9 4}$ & 9.32 & 20.28 & 4.83 & 12.09 & 4.93 \\
\hline$(4)$ (Lowest) & 1.59 & 4.95 & 4.80 & -1.43 & 11.70 & 5.19 & 3.90 & 7.58 & 3.95 \\
\hline Overall & 2.56 & 5.81 & 5.62 & 5.09 & 9.19 & 19.20 & 4.79 & 9.26 & 4.92 \\
\hline
\end{tabular}

Quartile number 1 includes the funds that have achieved the highest return in the last five years, while quartile number 4 includes the funds with the lowest return. The returns show the average quarterly data for the research period.

In Table 9 and Table 10, it is seen that the funds with high performance invest more in companies with low market value compared to other funds, and these preferences reflect positively on their performance. So why do some funds invest in small companies while others do not? There may be two different explanations for this. The first explanation is that large-scale funds cannot invest in relatively nonliquid small-scale companies. If this description applies to stock funds in Turkey, the equity funds having the highest performance should have lower portfolio values in comparison with the funds that have poor performances. The second explanation is that when the long-term XTUMY / XU100 performance is analyzed, small-scale companies that offer periodically high returns cannot sustain this performance in the long term and at the same time, they are not preferred by some funds because their higher price volatility and more frequent speculative pricing. To answer the question of which explanation is valid, the funds are listed in order of their returns and the average fund size and investment weights for large and small companies are given in Table 11. When Table 11 is analyzed, it is seen that four of the top five funds with the highest five-year return invest significantly higher in small-cap companies. This shows that these funds increase their returns by increasing the risk they are exposed to. Another finding obtained when examining the size and distribution of funds is that there is no relationship between the average fund size and the weight of investments made in small-scale companies. In other words, the thesis that funds with large scale assets cannot invest in small-cap due to the liquidity problem is not supported. 


\section{S. Ünal - M. Aydınlı 13/2 (2021) 1200-1215}

Table 11. The Funds' Stock Selections in Terms of Market Cap, Funds' Average Sizes During Last Five Years and Fund's Last Five Years Returns

\begin{tabular}{ccccc}
\hline $\begin{array}{c}\text { Fund } \\
\text { No }\end{array}$ & $\begin{array}{c}\text { B } \\
\text { Weight } \\
\mathbf{( \% )}\end{array}$ & $\begin{array}{c}\text { S } \\
\text { Weight } \\
(\mathbf{\%})\end{array}$ & $\begin{array}{c}\text { Funds } \\
\text { Average } \\
\text { Size } \\
\mathbf{( M T L )}\end{array}$ & $\begin{array}{c}\text { 5 Years } \\
\text { Return } \\
(\mathbf{\%})\end{array}$ \\
\hline 1 & 94.6 & $\mathbf{5 . 4}$ & 48.0 & 299.5 \\
\hline 2 & 99.7 & 0.3 & 23.6 & 259.5 \\
\hline 3 & 91.3 & $\mathbf{8 . 7}$ & 10.9 & 241.2 \\
\hline 4 & 86.8 & $\mathbf{1 3 . 2}$ & 65.9 & 217.8 \\
\hline 5 & 78.7 & $\mathbf{2 1 . 3}$ & 2.9 & 197.1 \\
\hline 6 & 100.0 & 0.0 & 26.7 & 164.2 \\
\hline 7 & 97.2 & 2.8 & 26.5 & 149.4 \\
\hline 8 & 98.1 & 1.9 & 7.0 & 132.3 \\
\hline 9 & 99.6 & 0.4 & 17.8 & 108.8 \\
\hline 10 & 100.0 & 0.0 & 20.6 & 103.5 \\
\hline 11 & 100.0 & 0.0 & 12.5 & 93.5 \\
\hline
\end{tabular}

\begin{tabular}{ccccc}
\hline $\begin{array}{c}\text { Fund } \\
\text { No }\end{array}$ & $\begin{array}{c}\text { B } \\
\text { Weight } \\
\mathbf{( \% )}\end{array}$ & $\begin{array}{c}\text { S } \\
\text { Weight } \\
\mathbf{( \% )}\end{array}$ & $\begin{array}{c}\text { Funds } \\
\text { Average } \\
\text { Size } \\
\mathbf{( M T L )}\end{array}$ & $\begin{array}{c}\text { 5 Years } \\
\text { Return } \\
\mathbf{( \% )}\end{array}$ \\
\hline 12 & 99.5 & 0.5 & 27.7 & 90.6 \\
\hline 13 & 99.6 & 0.4 & 16.6 & 82.6 \\
\hline 14 & 100.0 & 0.0 & 9.3 & 81.8 \\
\hline 15 & 99.8 & 0.2 & 38.8 & 76.5 \\
\hline 16 & 100.0 & 0.0 & 45.3 & 72.5 \\
\hline 17 & 99.8 & 0.2 & 38.8 & 70.9 \\
\hline 18 & 95.8 & 4.2 & 12.0 & 69.1 \\
\hline 19 & 100.0 & 0.0 & 3.1 & 67.0 \\
\hline 20 & 100.0 & 0.0 & 31.8 & 58.8 \\
\hline 21 & 99.8 & 0.2 & 6.2 & 57.5 \\
\hline 22 & 99.3 & 0.7 & 1.7 & 56.9 \\
\hline
\end{tabular}

\section{CONCLUSION AND DISCUSSION}

In this study, using data from 2015 to 2020, the significance of the equity fund returns reported in TEFAS for investors was analyzed. According to the findings of the study in which the data set was created and regression analysis was performed according to the FF3F model, (1) equity funds have lower beta values compared to the market; (2) they invest in companies that are discounted considering the BV / MV ratio and (3) they generally prefer companies with high market value for their investments.

Within the scope of the research, according to the last five years' return in TEFAS, the funds are divided into four different quartiles from the highest to the lowest. The stock selection of the funds in each quartile was analyzed in regression analysis separately. It is observed that the sensitivity of funds in 4 different quartiles to market risk is at similar levels. When the HML factor, which indicates the discount of value in the FF3F model, is examined, it is seen that the funds in the 3rd and 4th quartiles with relatively lower performance are more careful in choosing stocks and have a high HML factor coefficient. When the SMB factor is examined, it is seen that generally, all quartiles have a negative coefficient, but the quartile number 1 among them has a relatively higher SMB relationship. The main reason for this is that the funds in quartile 1 invest more in small-cap companies compared to funds in other quartiles. When the $C$ coefficient, which shows the alpha of the fund quartiles, is examined, it is seen that the first three quartiles have very close values and only the 4th quartile differentiates negatively from the others. This situation indicates that the divergence of performance difference between the first three fund quartiles is mostly due to the selected stock types; it also shows that their ability to overperform passive portfolios in share-based selections is close to each other and positive in all fund quartiles except the funds in the fourth quartile.

In the examinations conducted, there is a serious return difference between companies with small market value and high market value during the research period. While the average return of companies with small market value is $9.3 \%$, the average return of companies with high market value is only $4.8 \%$. In addition, when the long-term development of the XTUMY / XU100 ratio in Figure 1 is analyzed, it is seen that this performance variation is peculiar only to the recent period. Again, the fact that the P / E ratio is 10 in XU100 index representing large companies and is 74 in XTUMY index representing small companies indicates that this performance differentiation does not have a healthy basis. Four out of the top five high-performing funds cover a much higher proportion of small-cap companies compared to other funds. Considering the fund size, it has been determined that high performing funds also manage a higher amount of assets compared to other funds. This does not support the thesis that poor-performing funds are limited because they cannot find companies with the necessary liquidity when making investment decisions. This shows that higherperforming funds achieve this by taking higher risks. 


\section{S. Ünal - M. Aydınlı 13/2 (2021) 1200-1215}

When other studies in the literature are examined, it is seen that mostly the performance of stock funds is at or below the market return level. (Sevinç and Yakar, 2019; Yavuz and Altınırmak, 2018; Gökçen and Yalçın, 2015; Şahin, 2017; Korkmaz and Uygurtürk, 2008; Daniel et al., 1997). Considering that all fund quartiles have positive alpha within the scope of this study, the study differs from other studies in the literature. The number of studies finding similar results with this study is quite limited (Wang et al., 2019; Kuzubas et al., 2019).

As a result, it is thought that the performance data published on the TEFAS platform may be largely misleading, the funds show similar share selection ability except for the funds in the lowest quartile, and the divergence in performance is mostly due to the periodic high performance experienced in smaller stocks and the relatively high risk taken by some funds. Generally, equity funds in Turkey have a low beta, which means they are not highly affected by market returns. These funds prefer large market cap companies with value premium potential in their investments.

The findings obtained in this study are thought to be especially important for investors who are considering investing in equity funds in terms of evaluating the returns of the funds presented in the TEFAS platform.

In the future studies on this subject, researchers may (1) determine the stock groups that are subject to speculation and test whether the funds take such shares in their portfolios; (2) determine if the fund managers use window dressing to show their performance higher; and (3) extend the model used in this study to cover different emerging markets.

\section{REFERENCES}

Acaravc1, S. K. and Karaome, Y. (2017). FamaFrench five factor model: evidence from Turkey, International Journal of Economics and Financial Issues, 7(6), 130-137.

Alptekin, N. and Şıklar, E. (2009). Türk Hisse Senedi Emeklilik Yatırım Fonlarının Çok Kriterli Performans Değerlendirmesi: TOPSIS Metodu. Dumlupinar Üniversitesi Sosyal Bilimler Dergisi, (25).

Anadu, K., Kruttli, M. S., McCabe, P. E., Osambela, E. and Shin, C. (2019). The shift from active to passive investing: potential risks to financial stability?. Available at SSRN 3244467.

Aras, G., Çam, İ., Zavalsız, B. and Keskin, S. (2018). Fama-French Çok Faktör Varlık Fiyatlama Modellerinin Performanslarının Karşılaştıılması: Borsa İstanbul Üzerine Bir Uygulama. Istanbul University Journal of the School of Business Administration, 47(2).

Atakan, T. and Gökbulut, İ. (2010). Üç Faktörlü Varlik Fiyatlandirma Modelinin Istanbul Menkul Kiymetler Borsasi'nda Uygulanabilirliginin Panel Veri Analizi ile Test Edilmesi. Muhasebe ve Finansman Dergisi, (45).

Barak, O. (2007). Hisse senedi piyasasında halka açıklık oranının piyasa fiyati üzerine etkisi. Selçuk Üniversitesi Sosyal Bilimler Meslek Yüksekokulu Dergisi, 10(1-2), 59-72.

Belimam, D., Tan, Y. and Lakhnati, G. (2018). An empirical comparison of asset-pricing models in the Shanghai A-share exchange market. Asia-Pacific Financial Markets, 25(3), 249-265.

Bloomberg. (2020). https://www.bloomberg.com/quote/XU100:IND (Retrieved on July 20, 2020)

Bloomberght. (2020). QNB Finansbank'ın piyasa değeri borsanın \% 20'sine yaklaştı https://www.bloomberght.com/qnb-finansbank-in-piyasa-degeri-borsanin-20-sine-yaklasti-2244612 (Retrieved on July 25, 2020)

Broeders, D. W., Van Oord, A. and Rijsbergen, D. R. (2019). Does it pay to pay performance fees? Empirical evidence from Dutch pension funds. Journal of International Money and Finance, 93, 299-312.

Chan, L. K., Chen, H. L. and Lakonishok, J. (2002). On mutual fund investment styles. The Review of Financial Studies, 15(5), 1407-1437.

Chen, R., Gao, Z., Zhang, X. and Zhu, M. (2018). Mutual fund managers' prior work experience and their investment skill. Financial Management, 47(1), 3-24.

Coşkun, E. \& Çınar, Ö. (2014). Üç faktör varlık fiyatlama modelinin geçerliliği: Borsa İstanbul'da bir inceleme, Atatürk Üniversitesi İktisadi ve İdari Bilimler Dergisi, 28(4), 235-250. 


\section{S. Ünal - M. Aydınlı 13/2 (2021) 1200-1215}

Crane, A. D. and Crotty, K. (2018). Passive versus active fund performance: do index funds have skill?. Journal of Financial and Quantitative Analysis, 53(1), 33-64.

Daniel, K., Grinblatt, M., Titman, S. and Wermers, R. (1997). Measuring mutual fund performance with characteristic-based benchmarks. The Journal of Finance, 52(3), 1035-1058.

Deb, S. G. (2019). Persistence in performance of actively managed equity mutual funds: New Indian evidence. IIMB Management Review, 31(2), 145-156.

Dünya (2020a). Borsada yabanc1 payı, 16 yıl sonra \%50'nin altında! https://www.dunya.com/finans/haberler/borsada-yabanci-payi-16-yil-sonra-50nin-altinda-haberi474727 (Retrieved on July 22, 2020)

Dünya (2020b). Kent Gıda'nın değeri İş'i geçti! https://www.dunya.com/finans/haberler/kent-gidanin-degeriisi-gecti-haberi-474835 (Retrieved on July 24, 2020)

Ekonomist (2020). Borsa Nereye? https://www.ekonomist.com.tr/kapak-konusu/borsa-nereye.html (Retrieved on July 31, 2020)

Fama, E. F. and French, K. R. (1993). Common risk factors in the returns on stocks and bonds. Journal of Financial Economics, 33, 3-560

Fama, E. F. and French, K. R. (2015). A five-factor asset pricing model. Journal of Financial Economics, 123, 1-22.

Guzella, M. D. S. and Campani, C. H. (2017). Predictive power of Brazilian equity fund performance using R2 as a measure of selectivity. Revista Contabilidade \& Finanças, (AHEAD), 0-0.

Hanauer, M. X. and Lauterbach, J. G. (2019). The cross-section of emerging market stock returns. Emerging Markets Review, 38, 265-286.

Hunter, D., Kandel, E., Kandel, S. and Wermers, R. (2014). Mutual fund performance evaluation with active peer benchmarks. Journal of Financial Economics, 112(1), 1-29.

Genç, E. \& Çömlekçi, İ. (2018). Fama-French Üç Faktörlü Varlık Fiyatlama Modeli'nin Geçerliliği: Borsa İstanbul Üzerine Bir Araştırma. Yüzüncü Yıl Üniversitesi Sosyal Bilimler Enstitüsü Dergisi, (40), 257-276.

Gökçen, U. and Yalçın, A. (2015). The case against active pension funds: Evidence from the Turkish Private Pension System. Emerging Markets Review, 23, 46-67.

Guzella, M. D. S. and Campani, C. H. (2017). Predictive power of Brazilian equity fund performance using R2 as a measure of selectivity. Revista Contabilidade \& Finanças, (AHEAD), 0-0.

Kara, E. (2016). Testing Fama and French's threefactor asset pricing model: Evidence from Borsa Istanbul, Cankır Karatekin University Journal of the Faculty of Economics and Administrative Sciences. 6(1), 257-272.

Kaya, E. \& Güngör, B. (2017). Fama ve French üç faktörlü modeli'nin geçerliliğinin borsa istanbul için panel veri analizi ile araştırılması. Akademik Araştırmalar ve Çalışmalar Dergisi (AKAD), 9(17), 222-236.

Kesbiç, C. Y. and Taşdemir, B. M. (2019). Halka Açıklık Oranının Finansal Performans Üzerindeki Etkisi. Yönetim ve Ekonomi: Celal Bayar Üniversitesi İktisadi ve İdari Bilimler Fakültesi Dergisi, 26(2), 689-703.

Korkmaz, T. and Uygurtürk, H. (2008). Türkiye'deki emeklilik fonları ile yatırım fonlarının performans karşılaştırması ve fon yöneticilerinin zamanlama yetenekleri. Kocaeli Üniversitesi Sosyal Bilimler Enstitüsü Dergisi 15(1), 114-147.

Korteweg, A. and Sorensen, M. (2017). Skill and luck in private equity performance. Journal of Financial Economics, 124(3), 535-562.

Kuzubas, T. U., Saltoğlu, B., Sert, A. and Yüksel, A. (2019). Performance evaluation of the Turkish pension fund system. Journal of Capital Markets Studies, Vol. 3 No. 1, 2019, 18-33

Lee, J., Jeon, H., Kang, J. and Lee, C. (2020). Do Actively Managed Mutual Funds Exploit Stock Market Mispricing?. The North American Journal of Economics and Finance, 101189. 


\section{S. Ünal - M. Aydınlı 13/2 (2021) 1200-1215}

Meydan, C. and Yılmaz, T. (2020). BİST İmalat İşletmelerinde Kârlılık Üzerine Ampirik Bir Uygulama. Dumlupinar Üniversitesi Soysyal Bilimler Dergisi, (63).

Malkiel, B. G. (1995). Returns from investing in equity mutual funds 1971 to 1991. The Journal of Finance, 50(2), 549-572.

Pástor, L., Stambaugh, R. F. and Taylor, L. A. (2015). Scale and skill in active management. Journal of Financial Economics, 116(1), 23-45.

Robinson, D. T. and Şensoy, B. A. (2013). Do private equity fund managers earn their fees? Compensation, ownership, and cash flow performance. The Review of Financial Studies, 26(11), 2760-2797.

Sevinç, D. and Yakar, A. (2019). Türkiye'deki pay senedi yatırım fonlarının performans analizi. Anadolu Üniversitesi İktisadi ve İdari Bilimler Fakültesi Dergisi, 20(2), 112-129.

Setiawan, C. and Kanila Wati, N. P. (2019). Factors Affecting the Performance of Sharia Equity Funds in Indonesia. Iranian Journal of Management Studies, 12(4), 481-508.

Sharpe, W. F. (1964). Capital asset prices: A theory of market equilibrium under conditions of risk. The Journal of Finance, 19, 425-442

Silva, S. E. D., Roma, C. M. D. S. and Iquiapaza, R. A. (2020). Portfolio turnover and performance of equity investment funds in Brazil. Revista Contabilidade \& Finanças, 31(83), 332-347.

SPK. (2013). Yatırım Fonlarına İlişkin Esaslar Tebliği, (III-52.1). http://mevzuat.spk.gov.tr/MevzuatDosya.aspx?nid=134521\&dt=2 (Retrieved on July 31, 2020)

Şahin, A. (2017). BİST 30 Endeks Fonlarının Seçme ve Zamanlama Yeteneği. Business and Economics Research Journal, 8(1), 63-81.

Tarı, R. (2018). Ekonometri, Umuttepe Yayınları, 13. Baskı, Kocaeli.

Temizel, F. and Bayçelebi, B. B. (2016). Türkiye'deki yatırım fonlarının etkinliğe dayalı performans değerlemesi. Aksaray Üniversitesi Iktisadi ve İdari Bilimler Fakültesi Dergisi, 8(4), 11-31.

Yalçıner, B. (2019). Türkiye'de hisse senedi yatırım fonları ne kadar aktif yönetiliyor. In 7-8-9 november 2019 gaziantep IERFM 3. Internatıonal Economic Reserach and Financial Markets Congress Proceeding Book (vol. 7, p. 135).

Yavuz, G. U. L. and Altınırmak, S. (2018). Evaluation of the performance of Turkish equity umbrella funds using the morningstar rating system. Journal of Economics Finance and Accounting, 5(1), 127-136.

Wang, Y., Paek, M. and Ko, K. (2019). The performance of Chinese equity funds: An extension of DGTW model. Japan and the World Economy, 51, 100964.

Zeren, F., Yılmaz, T. and Belke, M. (2019). Testing The Validity Of Fama French Five Factor Asset Pricing Model: Evidence From Turkey1. Financial Studies, 23(2), 97-113. 